\author{
제주재래돼지의 성별 및 도체등급에 따른 도체특성 분석 \\ 김계 ${ }^{1}{ }^{*} \cdot$ 유재영 ${ }^{1} \cdot$ 김건중 $^{1} \cdot$ 이종완 ${ }^{1} \cdot$ 김영봉 $^{2} \cdot$ 민근홍 $^{3} \cdot$ 김석은 $^{1}{ }^{*}$ \\ ${ }^{1}$ 공주대학교 산업과학대학 동물자원학과, ${ }^{2}$ 건국대학교 동물생명과학대학 동물생명과학과, ${ }^{3}$ (주)참거리
}

\title{
Analysis of Carcass Characteristics by Gender and Carcass Grades of Jeju Native Pigs
}

\author{
Gye Woong Kim ${ }^{1} *$, Jae Young Yoo ${ }^{1}$, Kon Joong Kim ${ }^{1}$, Jong Wan Lee', Young Bong Kim², Keun Hong Min ${ }^{3}$, Seok Eun Kim ${ }^{1} * *$ \\ ${ }^{1}$ Dept. of Animal Resources Science, College of Industrial Sciences, Kongju National University, \\ ${ }^{2}$ Dept. of Animal Biotechnology, College of Animal Bioscience \& Technology, Konkuk University, ${ }^{3}$ Chamgeori Co. Ltd.
}

\begin{abstract}
The Jeju native pigs of 168 heads (116 barrows and 52 gilts) were examined to investigate the carcass characteristics related to gender, meat quality grades and yield grades. The averages of carcass characteristics for Jeju native pigs were $72.94 \mathrm{~kg}$ for carcass weight, $20.98 \mathrm{~mm}$ for backfat thickness, 38.14 for Hunter $\mathrm{L}^{*}, 4.68$ for $\mathrm{a}^{*}, 6.04 \mathrm{for}^{*}, 5.61$ for $\mathrm{pH}, 3.61$ for visual plate meat color, 3.36 for marbling scores, 1.83 for meat quality grades and 2.08 for yield grades, respectively. The carcass weight of gilts was significantly higher than that of barrows $(\mathrm{p}<0.05)$. There were no significant differences between barrows and gilts in carcass percent, backfat thickness, and meat color. The $\mathrm{pH}$ of barrows was significantly higher than that of gilts $(\mathrm{p}<0.05)$. The differences between gender groups were significantly noticed in carcass quality grades, and yield grades $(p<0.05$ ). The carcass weight, carcass percent, backfat thickness, and marbling scores for pigs with high grades $(1$ and 2 grades $)$ were significantly higher than those for pigs with low grades $(\mathrm{p}<0.05)$. However, there was no significant difference among 4 carcass grades. The carcass weight, carcass percent, backfat thickness, $\mathrm{pH}$, and meat color for carcass with high yield grades were significantly higher than those for carcass with low grades $(\mathrm{p}<0.05)$. The meat colors for Hunter $\mathrm{L}^{*}, \mathrm{a}^{*}$ and $\mathrm{b}^{*}$ were not significantly shown in carcass yield grades.
\end{abstract}

(Key words : Carcass characteristics, Gender, Carcass grades, Jeju native pigs)

\section{서 론}

우리나라의 2008 년도 1 인당 총 육류소비량은 $35.6 \mathrm{~kg}$ 중 돼지고 기는 $19.1 \mathrm{~kg}$ 으로 소비 비중이 가장 컸으며, 그 다음으로 닭고기, 쇠고기 순이었다(농림수산식품부, 2010). 최근 소비자들은 등지방 두께가 얇고 위생적인 돼지고기를 더욱 요구하고 있어 생산자는 양 질의 돼지고기를 생산하도록 돼지 품종선택과 사양관리 시스템 개 발에 더 한층 노력해야 할 것이다.

우리나라 재래돼지는 약 2,000 3000년 전에 만주에서 한반도로 전해져서 사육해온 것으로 알려지고 있다. 이러한 재래돼지는 제주, 지례, 강화 등에서 사육되고 있으며, 유전적 특징으로 체격이 왜소 하고, 피모가 흑색이며, 조악한 환경에서도 잘 견디는 성질을 가지 고 있다(이 등, 2005). 지금까지의 돼지고기는 등지방 두께가 얇 고, 체지방 축적이 낮으며, 사료효율 개선이나 산육성 개량 등 생 산성 향상을 위한 살코기형 돼지를 선발하여 육질보다는 육량위주
로 생산해 왔다(Larzul 등, 1997; Choi, 2004; 조 등, 2007a). 대 부분의 재래종은 개량종에 비하여 체구가 작고, 만숙종이며, 오랫 동안 검정 버크셔종과의 교배로 외모색이 한가지로 고정되지 못한 아쉬움을 가지고 있다. 우리 재래돼지고기가 다른 품종에 비하여 지방이 단단하고 백색이며 맛이 좋고, 육질이 쫄깃하고 부드러워 우리나라 사람들의 기호에 잘 맞는 것으로 알려져 있다(Kwon, 2006; 조 등, 2007a). 돼지고기의 품질은 품종, 사양방법, 영양수 준, 도축이나 가공방법 등에 의해서 영향을 받으며, 특히 품종은 육질에 많은 영향을 미치는 것으로 보고되었다(Martens, 1998; Warris 등, 1995; 오 등, 2008).

국내의 비육돈은 랜드레이스, 요크셔, 듀록종 등을 교배하여 생 산하는 $\mathrm{LYD}$ 또는 $\mathrm{YLD}$ 와 같은 3원 교잡종이 가장 널리 이용되고 있는데, 이는 다른 품종에 비하여 산자수가 높고, 성장이 빠르며, 고기생산량도 높기 때문이다 (Hong 등, 2001; Jin 등, 2006). 최 등 (1996)은 돼지 품종에 따른 도체특성에서 랜드레이스, 요크셔,

\footnotetext{
* Corresponding author: G. W. Kim, Dept. of Animal Resources Science, Kongju National University \# 1 Daehoeri, Yesan, Chungnam 340-702, Korea. Tel: 041-330-1245, Fax: 041-330-1249, E-mail: kimgoong @kongju.ac.kr

S. E. Kim, Dept. of Animal Resources Science, Kongju National University \# 1 Daehoeri, Yesan, Chungnam 340-702, Korea. Tel: 041-330-1240, Fax: 041-330-1249, E-mail: sekim@kongju.ac.kr
} 
듀록, 햄프셔, 삼원교잡종 사이에 도체율과 정육량에는 유의한 차 이가 없는 것으로 보고하였으며, Sather(1991)도 품종에 따라 도 체특성에는 유의적 차이가 없고, 성별로도 적육량이나 지방, 뼈 등 의 비율에 유의적인 차이없이 유사한 결과로 보고하였다. 재래돼지 고기는 랜드레이스종 고기보다 육색이 붉고 백색의 지방을 가지며, 근섬유소가 많으면서 가늘어 연한 특성이 있다(Jin 등, 2001). 조 등 (2007a)은 재래돼지가 일반 개량종보다 육색이 붉고 마블링이 잘 되는 특성을 가지고 있으며, 성별이나 출하체중별 요인에 따라 생산수율과 육질특성에 차이를 보였으며, 재래돼지의 육색도에서 $\mathrm{L}^{*}$ 값(백색도)과 $\mathrm{b}^{*}$ 값(황색도)은 암퇘지가 수퇘지보다 유의하게 높은 것으로 나타났으나 $(\mathrm{p}<0.05), \mathrm{a}$ 값 $($ 적색도)에서도 유의차는 없지만 짙은 경향을 보였다(조 등, 2007b). 비육돈의 경우 성별과 도체중은 마블링, 육질등급 및 육량등급에 유의한 차이를 보였으나 $(\mathrm{p}<0.01)$, 육색도에서는 모두 유의한 차이가 없고, 성별 간에 등지 방두께, 도체중 및 도체율에는 유의적 차이를 보인 것으로 보고되 고 있다(박 등, 2009).

본 연구는 제주재래돼지 암·수 168 두를 대상으로 도체등급 판 정을 받아 성별, 육질등급별 및 육량등급별로 구분하여 도체 및 육 질과 관련된 특성을 규명하여 우량 재래돼지고기 생산을 통하여 양 돈농가의 생산성 향상에 필요한 기초적 자료를 얻고자 수행하였다.

\section{재료 및 방법}

\section{1. 공시재료}

본 연구는 제주지역에서 사육된 재래돼지 거세돈 116 두와 암퇘 지 52두, 총 168 두를 공시재료로 이용하였다. 재래돼지는 N.R.C 사양표준에 따른 동일한 $\mathrm{N}$ 사료를 급여하였고, 일반사양관리에 준 하여 사육하였으며, 일반적으로 출하되고 있는 약 210 일령 전후에 도살하여 육질관련 자료를 얻었다. 재래돼지의 성별 (거세돈과 암퇘 지), 육질등급별(1-3), 그리고 육량등급별 (A-D) 분포는 Table 1과 같다.

Table 1. Distribution of Jeju native pigs used in this experiment

\begin{tabular}{lccc}
\hline Classification & & $\mathrm{N}$ & $\%$ \\
\hline \hline \multirow{2}{*}{ Gender } & Male & 116 & 69.0 \\
& Female & 52 & 31.0 \\
\hline \multirow{2}{*}{ Meat quality (Grades) } & 1 & 50 & 29.8 \\
& 2 & 96 & 57.1 \\
& 3 & 22 & 13.1 \\
\multirow{2}{*}{ Meat yield (Grades) } & $\mathrm{A}$ & 12 & 7.1 \\
& $\mathrm{~B}$ & 38 & 22.6 \\
& $\mathrm{C}$ & 70 & 41.7 \\
Total & $\mathrm{D}$ & 48 & 28.6 \\
\hline
\end{tabular}

\section{2. 조사항목 및 방법}

5 개 양돈농장에서 출하한 재래돼지를 제주 $\mathrm{H}$ 도축장에서 도축 후 박피하여 돼지 도체등급 판정기준에 의하여 등급사에 따라 5 등급 으로 판정하였다. 도체중은 이분도체의 온도체의 무게를 측정하였 고, 등지방두께는 $5^{\circ} \mathrm{C}$ 이하로 예냉된 도체 등(背)의 최후 늑골 부 위를 직각으로 절단하여 지방층의 두께를 측정하였다. 표면 육색도 는 등심 절단부를 Colour meter (Model NF333, Nippon Denshoku Co. Japan)를 이용하여 Hunter 값으로 $\mathrm{L}^{*}$ (명도), $\mathrm{a}^{*}$ (적색도), 그리고 $\mathrm{b}^{*}$ (황색도) 값을 5 회 반복하여 평균값으로 표시 하였으며, 이때의 표준판은 $\mathrm{Y}=92.40, \mathrm{x}=0.3136, \mathrm{y}=0.3196$ 의 백색 타일을 사용하였다. 표준판에 의한 육색도는 우리나라 육질기준표 (No. 1-7)를 사용하여 조견표에 따라 엷은 색은 1점에서 가장 짙 은 것은 7점을 부여하여 수치화로 표시하였으며, 근내지방도는 최 장근 단면의 근내지방 침착정도를 근내지방조견표(No. 1-5)를 이 용하여 마블링이 약하게 침착된 육단면은 1점에서 많은 상태는 5 점까지 부여하여 산술적 점수화로 나타났다. $\mathrm{pH}$ 는 등심심부에 $\mathrm{pH}$ meter bar를 이용하여 직접 측정하였다. 육질등급은 총 3 등급으로 1 등급은 1,2 등급은 2 , 그리고 3 등급은 3 으로 수치화하여 표시하 였으며, 육량등급점수는 $\mathrm{A}$ 등급은 4점에서 $\mathrm{D}$ 등급은 1점으로 도체 등급별로 수치화하여 표시하였다.

\section{3. 통계분석}

도체자료는 SAS (Statistical Analysis System, 1997) 프로그램 을 이용하여 평균과 표준편차를 구하였다. 각 조사항목의 성별 간 에는 t-test, 그리고 등급 간에는 Duncan의 다중검정으로 $5 \%$ 수준 에서 유의성을 검정하여 분석하였다.

\section{결과 및 고찰}

\section{1. 제주재래돼지의 평균 도체특성}

제주재래돼지의 도체특성에 대한 전체 평균과 표준편차는 Table 2 와 같다.

도체중 평균은 $72.94 \mathrm{~kg}$ 이었으며, 도체율은 $72.46 \%$ 로 나타났다. 등지방 두께는 $20.98 \mathrm{~mm}$ 이었고, 육색도에서 Hunter L* 값 (명도) 은 38.14, a* 값 (적색도)은 4.68, 그리고 $\mathrm{b}^{*}$ 값 (황색도)은 6.04 로 나타났다. $\mathrm{pH}$ 는 5.61이었으며, 육색도판 (No. 1-7)에 의한 육 색은 3.61이었고, 근내 마블링 수준은 3.36이었다. 육질등급 (1-3) 은 평균 1.83 이었고, $\mathrm{A}$ 등급은 4점과 $\mathrm{D}$ 등급은 1점으로 표기화된 평균 육량등급은 2.08로 나타났다.

이러한 결과는 최 등 (2005)이 재래흑돼지의 경우 평균 도체중이 $54.96 \mathrm{~kg}$ 이라고 보고한 것과 비교하여 무거운 것으로 나타났는데, 이는 사료나 출하일령, 지역품종 등의 차이에 기인한 것으로 사료 되며, Hunter L* 값은 39.99로 보고한 결과와 유사한 것이나 적색 
Kim et al. ; Carcass Characteristics of Jeju Native Pigs

Table 2. Overall mean and standard deviation for carcass characteristics in Jeju native pigs

\begin{tabular}{lllc}
\hline Carcass Traits & Mean \pm S.D & Carcass Traits & Mean \pm S.D \\
\hline \hline Carcass weight $(\mathrm{kg})$ & $72.94 \pm 5.17$ & $\mathrm{pH}$ & $5.61 \pm 0.13$ \\
Carcass \% & $72.46 \pm 1.35$ & Meat colour (1-7) & $3.61 \pm 1.00$ \\
Backfat thickness & $20.98 \pm 4.31$ & Marbling scores (1-5) & $3.36 \pm 1.31$ \\
Hunter L* & $38.14 \pm 3.80$ & Meat quality grades (1-3) & $1.83 \pm 0.64$ \\
$\mathrm{a}^{*}$ & $4.68 \pm 1.65$ & Meat yield grades (A-D) & $2.08 \pm 0.89$ \\
$\mathrm{~b}^{*}$ & $6.04 \pm 1.21$ & - & - \\
\hline
\end{tabular}

1) $1=$ pale, $7=$ dark purple red

2) $1=$ poor marbling, $5=$ excellent marbling.

도와 황색도를 나타내는 $\mathrm{a}^{*}$ 와 $\mathrm{b}^{*}$ 값은 각각 8.79 와 3.85 로 보고 한 결과와 다소 차이가 있는 것으로 보고하였다. 또한 재래돼지 도 체에서 재래돼지가 개량종보다 육색이 붉고 마블링이 잘되는 특징 을 가지고 있으며, 육색도 CIE L* 값은 거세수퇘지의 경우는 체 중이 증가할수록 낮아지나, 암퇘지는 체중이 증가할수록 높아졌다 (조 등, 2007a). 그리고 이 등 (2005)은 개량종보다 재래종에서 $\mathrm{L}^{*}$ 값이 낮고, 적색도 $\left(\mathrm{a}^{*}\right)$ 는 높은 것으로 보고하였고, 재래종 등지방 두께는 $28.0 \mathrm{~mm}$ 와 $\mathrm{pH}$ 는 5.75 로 보고한 결과보다 등지방 두께에 서는 얇았으나, $\mathrm{pH}$ 에서는 유사하였다.

\section{2. 성별에 따른 도체특성}

제주재래돼지의 거세돈과 암퇘지에 대한 도체특성을 분석한 결과 는 Table 3 과 같다. 도체중은 거세돈과 암퇘지에서 각각 $71.71 \mathrm{~kg}$ 과 $75.69 \mathrm{~kg}$ 으로 암퇘지에서 유의하게 무거웠다 $(\mathrm{p}<0.05)$. 도체율 은 거세돈이 $72.50 \%$ 와 암퇘지는 $72.38 \%$ 로 성별 간에는 유의한 차이가 없었다. 이러한 도체중은 개랑종의 경우, 최 등 (2000)과 김 과 임 (2006)이 성별 도체중은 유의한 차이가 없다는 결과와 차이 가 있었으나, 박 등 (2005)의 결과와는 유사한 결과를 보였다. 그리 고 조 등 $(2007 \mathrm{a})$ 이 재래돈 암퇘지와 거세돈의 도체율은 각각 $73.25 \%$ 와 $71.95 \%$ 로 보고한 결과와도 서로 대체적으로 유사하 였다.

등지방 두께는 성별 간에 유의한 차이를 보이지 않았으나, 암퇘 지 $20.69 \mathrm{~mm}$ 보다는 거세돈이 $21.00 \mathrm{~mm}$ 로 거세돈의 등지방 두께 가 다소 두꺼운 경향을 보였다. 이러한 결과는 최 등 (2008)이 거 세돈이 암퇘지보다 두껍다는 결과와 비슷하였다.

육색도는 Hunter $\mathrm{L}^{*}$ 값은 거세돈과 암퇘지에서 각각 38.26 과 $37.87, \mathrm{a}^{*}$ 값은 각각 4.72 와 4.59 , 그리고 $\mathrm{b}^{*}$ 값은 각각 6.10 과 5.91로 모두 성별 간에는 유의한 차이가 없었다. 이러한 결과는 조 등 $(2007 \mathrm{~b})$ 이 $\mathrm{L}^{*}$ 값과 $\mathrm{a}^{*}$ 값에서 성별 간에는 유의한 차이가 없다 는 보고와 일치하였으나, $b^{*}$ 값에서는 유의한 차이를 보였다는 결 과와는 다소 차이를 보였다.

$\mathrm{pH}$ 는 암퇘지 5.58 과 거세돈 5.62로 거세돈이 유의하게 높은 것 으로 나타났다 $(\mathrm{p}<0.05)$. 재래종과 개량종의 $\mathrm{pH}$ 보고에서 이 등
Table 3. Mean and standard deviation of carcass characteristics for male and female of Jeju native pigs

\begin{tabular}{lcc}
\hline \multicolumn{1}{c}{ Gender } & Male & Female \\
\hline Carcass Traits & $71.71 \pm 5.11^{\mathrm{b}}$ & $75.69 \pm 4.20^{\mathrm{a}}$ \\
Carcass weight $(\mathrm{kg})$ & $72.50 \pm 1.38$ & $72.38 \pm 1.30$ \\
Carcass \% & $20.10 \pm 4.79$ & $20.69 \pm 2.97$ \\
Backfat thickness (mm) & $38.26 \pm 3.83$ & $37.87 \pm 3.75$ \\
Hunter L* & $4.72 \pm 1.66$ & $4.59 \pm 1.64$ \\
$\quad \mathrm{a}^{*}$ & $6.10 \pm 1.18$ & $5.91 \pm 1.25$ \\
$\quad \mathrm{~b}^{*}$ & $5.62 \pm 0.14^{\mathrm{a}}$ & $5.58 \pm 0.11^{\mathrm{b}}$ \\
pH $\quad 3.64 \pm 0.98$ & $3.54 \pm 1.06$ \\
Meat colour (1-7) & $3.29 \pm 1.29$ & $3.50 \pm 1.35$ \\
Marbling scores (1-5) & $1.95 \pm 0.63^{\mathrm{a}}$ & $1.58 \pm 0.57^{\mathrm{b}}$ \\
Meat quality grades (1-3) & $1.90 \pm 0.83^{\mathrm{b}}$ & $2.50 \pm 0.90^{\mathrm{a}}$ \\
\hline Meat yield grades (A-D) &
\end{tabular}

${ }^{\mathrm{a}, \mathrm{b}}$ Values with different superscripts are significantly different $(\mathrm{p}<0.05)$.

(2005)은 저장기간에 따른 $\mathrm{pH}$ 결과는 차이가 없으나, 박 (2005)은 품종 간에 유의한 차이가 있다고 보고하였다.

육색기준표에 의한 육색에서도 성별 간에는 유의한 차이가 없었 으나 암퇘지보다는 거세돈에서 다소 짙은 경향을 보였다. 이러한 결과는 김과 임 (2006)이 보고한 비육돈에서 성별 간의 육색도는 유의한 차이가 없다는 보고와 일치하였다.

도체 육질등급에서는 암퇘지와 거세돈의 평균등급은 1.58 과 1.95 으로 조사되었는데, 거세돈에서 유의하게 높은 등급을 보였다 $(\mathrm{p}<0.05)$. 이러한 재래돈의 결과는 개량종에서 성별 간이나 사료급 여수준 간에 유의한 차이가 있다는 박 등 (2009)의 결과와 유사하 였다. 또한 진 등 (2005)은 사천재래종에서 도살체중별 간에도 유 의차가 있는 것으로 보고한 바도 있다.

육량등급은 $\mathrm{A}$ 등급은 4점에서 $\mathrm{D}$ 등급은 1점까지 평균한 점수는 거세돈과 암퇘지에서 각각 2.50 점과 1.90 점으로 성별 간에는 유의 한 차이를 보였다 $(\mathrm{p}<0.05)$. 거세돈보다는 암퇘지에서 높은 등급을 
보였는데, 이는 거세돈보다는 암퇘지에서 육량규격을 판정하는 도 체중, 등지방두께, 비육상태, 지방부착상태 등이 양호한데 기인한 것으로 사료된다. 이 결과는 박 등 (2009)이 개량종의 경우 암퇘지 와 거세돈 간에는 유의한 차이가 없다는 보고와는 서로 상이한 결 과로 나타났다.

\section{3. 도체 육질등급별 도체특성}

재래돼지의 거세돈과 암퇘지의 도체등급별 도체특성은 Table 4 와 같다. 도체중은 육질등급 간에 유의한 차이를 보였는데, 도체등 급이 높을수록 도체중은 무거운 것으로 나타났다 $(\mathrm{p}<0.05)$. 도체율 에서도 도체등급 간에 유의한 차이를 보였는데, 3 등급 보다는 1 과 2 등급 같은 상위 등급에서 높게 나타났다 $(\mathrm{p}<0.05)$.

등지방 두께는 1 등급은 $22.72 \mathrm{~mm}$ 로 3 등급 $15.73 \mathrm{~mm}$ 보다 유 의하게 높은 지방층 두께를 보였다 $(\mathrm{p}<0.05)$. 따라서 하위등급보다 는 상위 육질등급일수록 등지방 두께가 두꺼운 것을 알 수 있었다. 육색도는 Hunter $\mathrm{L}^{*}$ 값, $\mathrm{a}^{*}$ 값, 그리고 $\mathrm{b}^{*}$ 값은 각각 모두 유의한
차이없이 등급 간에 비슷한 육색으로 나타났다. $\mathrm{pH}$ 에서도 등급 간 에 유의한 차이없이 1 등급 5.59에서 3등급 5.62로 서로 비슷한 값 을 보였다. 육색도판에 의한 육색에서도 육질등급 간에 유의한 차 이가 없이 서로 비슷한 경향으로 나타났다. 근내지방도는 육질등급 간에 유의한 차이를 보였는데 $(\mathrm{p}<0.05), 1$ 등급은 4.06점에서 3 등급 은 2.64점으로 등급이 높을수록 높은 점수를 얻었다. 이러한 결과 는 육질등급을 결정해주는 요인으로는 마블링상태가 주요인으로 작 용했기 때문으로 사료된다.

\section{4. 도체 육량등급별 도체특성}

재래돼지의 도체등급별 도체특성은 Table 5 에 나타난 바와 같다. 도체중은 육량등급 간에 유의차를 보였는데 $(\mathrm{p}<0.05), \mathrm{A}$ 등급은 $82.17 \mathrm{~kg}$ 에서 $\mathrm{D}$ 등급은 $66.75 \mathrm{~kg}$ 으로 도체등급이 높을수록 도체중 이 무거운 것으로 나타났다. 이러한 결과는 진 등(2004)의 재래종 과 랜드레이스 교잡종에서 도체중이 무거울수록 상위 $\mathrm{A}, \mathrm{B}$ 등급 출현율이 높았다는 결과와 일치하였다. 도체율에서도 도체등급 간

Table 4. Mean and standard deviation of carcass characteristics by carcass quality grades of Jeju native pigs

\begin{tabular}{lccc}
\hline & Quality grades & 1 & 2 \\
Carcass Traits & $78.76 \pm 2.29^{\mathrm{a}}$ & $71.10 \pm 3.71^{\mathrm{b}}$ & $67.73 \pm 3.73^{\mathrm{c}}$ \\
\hline \hline Carcass weight (kg) & $72.26 \pm 1.00^{\mathrm{ab}}$ & $72.69 \pm 1.37^{\mathrm{a}}$ & $71.95 \pm 1.77^{\mathrm{b}}$ \\
Carcass \% & $22.72 \pm 3.11^{\mathrm{a}}$ & $21.27 \pm 4.21^{\mathrm{a}}$ & $15.73 \pm 2.87^{\mathrm{b}}$ \\
Backfat thickness (mm) & $38.31 \pm 3.92$ & $38.08 \pm 3.65$ & $38.00 \pm 4.30$ \\
Hunter L* & $4.71 \pm 1.42$ & $4.64 \pm 1.89$ & $4.81 \pm 0.79$ \\
$\quad \mathrm{a}^{*}$ & $6.06 \pm 1.26$ & $6.07 \pm 1.19$ & $5.88 \pm 1.18$ \\
$\quad \mathrm{~b}^{*}$ & $5.62 \pm 0.14$ & $5.61 \pm 0.13$ & $5.59 \pm 0.15$ \\
$\mathrm{pH} \quad 3.80 \pm 1.07$ & $3.50 \pm 0.96$ & $3.64 \pm 1.00$ \\
Meat colour (1-7) & $4.04 \pm 1.16^{\mathrm{a}}$ & $3.17 \pm 1.27^{\mathrm{b}}$ & $2.64 \pm 1.18^{\mathrm{b}}$ \\
Marbling scores (1-5) &
\end{tabular}

${ }^{a, b, c}$ Values with different superscripts are significantly different $(\mathrm{p}<0.05)$.

Table 5. Mean and standard deviation of carcass characteristics by meat yield grades of Jeju native pigs

\begin{tabular}{|c|c|c|c|c|}
\hline $\begin{array}{ll} & \text { Yield grades } \\
\text { Carcass Traits } & \end{array}$ & $\mathrm{A}$ & $\mathrm{B}$ & $\mathrm{C}$ & $\mathrm{D}$ \\
\hline Carcass weight $(\mathrm{kg})$ & $82.17 \pm 1.27^{\mathrm{a}}$ & $77.68 \pm 1.23^{\mathrm{b}}$ & $73.03 \pm 1.45^{\mathrm{c}}$ & $66.75 \pm 3.37^{\mathrm{d}}$ \\
\hline Carcass \% & $73.05 \pm 0.68^{\mathrm{a}}$ & $72.06 \pm 0.96^{\mathrm{b}}$ & $73.06 \pm 1.18^{\mathrm{a}}$ & $71.81 \pm 1.54^{\mathrm{b}}$ \\
\hline Backfat thickness (mm) & $22.83 \pm 2.92^{\mathrm{a}}$ & $22.68 \pm 3.21^{\mathrm{a}}$ & $21.34 \pm 4.32^{\mathrm{a}}$ & $18.63 \pm 4.39^{\mathrm{b}}$ \\
\hline Hunter L* & $38.75 \pm 3.74$ & $38.17 \pm 4.02$ & $38.26 \pm 3.75$ & $37.77 \pm 3.80$ \\
\hline $\mathrm{a}^{*}$ & $4.13 \pm 0.56$ & $4.89 \pm 1.56$ & $4.55 \pm 1.87$ & $4.84 \pm 1.53$ \\
\hline$b^{*}$ & $5.64 \pm 1.30$ & $6.19 \pm 1.23$ & $6.02 \pm 1.23$ & $6.06 \pm 1.13$ \\
\hline $\mathrm{pH}$ & $5.53 \pm 0.10^{b}$ & $5.64 \pm 0.14^{\mathrm{a}}$ & $5.61 \pm 0.15^{\mathrm{a}}$ & $5.61 \pm 0.10^{\mathrm{a}}$ \\
\hline Meat colour (1-7) & $3.33 \pm 1.16^{\mathrm{b}}$ & $3.95 \pm 1.01^{\mathrm{a}}$ & $3.54 \pm 1.06^{\mathrm{ab}}$ & $3.50 \pm 0.83^{\mathrm{ab}}$ \\
\hline Marbling scores (1-5) & $4.00 \pm 0.85^{\mathrm{a}}$ & $4.05 \pm 1.25^{\mathrm{a}}$ & $3.06 \pm 1.25^{\mathrm{b}}$ & $3.08 \pm 1.30^{\mathrm{b}}$ \\
\hline
\end{tabular}

${ }_{\text {a,b,c,d }}$ Values with different superscripts are significantly different $(\mathrm{p}<0.05)$. 
에 유의한 차이로 나타났다 $(\mathrm{p}<0.05)$. 등지방 두께는 A 등급은 $73.05 \%$ 인 반면에 D 등급은 $71.81 \%$ 로 등급이 낮을수록 도체율은 떨어졌다. 등지방 두께는 $\mathrm{A}$ 등급과 $\mathrm{B}$ 등급의 경우 각각 22.83 $\mathrm{mm}$ 와 $22.68 \mathrm{~mm}$ 이었으나, $\mathrm{D}$ 등급은 $18.63 \mathrm{~mm}$ 를 보였는데, 도 체등급이 높을수록 유의하게 등지방 두께가 두꺼운 결과를 보였다 $(\mathrm{p}<0.05)$. 이러한 결과는 진 등 $(2004)$ 이 재래종 교잡종에서 등급 간에 유의한 차이가 있었는데, 도체 육량등급이 높을수록 등지방 두께가 높고 낮을수록 얇다는 보고와 대체적으로 유사한 결과를 보 였으나, 김과 김 (2009)이 개량잡종에서는 등급 간에 유의성은 있 고, 등급이 높을수록 얇다는 보고와 서로 상이한 결과를 나타났다.

육색도는 Hunter $\mathrm{L}^{*}$ 값, $\mathrm{a}^{*}$ 값 및 $\mathrm{b}^{*}$ 값 모두 등급 간에 유의 한 차이없이 비슷한 경향을 보였으나, $\mathrm{pH}$ 값은 $\mathrm{A}$ 등급에서 5.53 으로 낮으나, B, C, D 등급에서는 유의하게 높은 것으로 나타났다 $(\mathrm{p}<0.05)$. 이러한 결과는 진 등 $(2004)$ 의 도체등급 간에 $\mathrm{pH}$ 값은 유의차가 없다는 결과와 서로 상이함을 보였다. 육색도판에 의한 육색은 도체등급 간에 유의한 차이를 보였다 $(\mathrm{p}<0.05) . \mathrm{B}$ 등급에서 3.95 로 가장 높은 반면에 A 등급은 3.33으로 가장 낮게 나타났는 데, 이러한 결과는 김과 김 (2009)이 개량교잡종에서 유의차는 없 지만 $\mathrm{A}$ 등급에서 가장 낮은 경향을 보였다는 결과와 대체적으로 유사한 것으로 나타났다. 근내지방도는 $\mathrm{A}$ 등급과 $\mathrm{B}$ 등급에서는 각 각 4.00과 4.05점, 그리고 $\mathrm{C}$ 와 $\mathrm{D}$ 등급은 3.06 과 3.08 점으로 상하 등급 간에 유의한 차이를 보였는데 $(\mathrm{p}<0.05)$, 이는 $\mathrm{A}$ 와 $\mathrm{B}$ 등급과 같은 상위등급 개체에서는 근내 마블링이 많이 축적되었기 때문으 로 사료된다. 이러한 결과는 진 등 (2004)이 재래종 교잡에서 유의 차는 없지만 상위등급 $(\mathrm{A}$ 와 $\mathrm{B}$ 등급 $)$ 에서 하위등급 $(\mathrm{C}$ 와 $\mathrm{D})$ 보다 높은 것으로 보고한 결과와 유사한 경향을 보였다.

이상의 결과로 보아, 제주재래종은 개랑종보다 도체중에서는 가 벼웠으나, 등지방두께는 얇은 것으로 나타났으며, 육질이나 육량등 급에서는 비슷한 결과로 나타났다. 따라서, 육질특성과 관련된 심 도있는 품종간 연구와 함께 정확한 평가가 이루어져야 할 것으로 사료된다.

\section{요 약}

본 연구는 도체등급을 판정받은 제주재래돼지 168 두(거세돈 116 두와 암퇘지 52두)를 공시돈으로 재래돼지의 성별, 도체 육질 등급별 및 육량등급별 도체특성을 조사하여 고급돈육 생산에 필요 한 기초자료를 얻고자 실시하였다.

재래돼지의 도체특성의 평균치는 도체중이 $72.94 \mathrm{~kg}$, 도체율 $72.46 \%$, 등지방두께 $20.98 \mathrm{~mm}$, Hunter L* 값 38.14 , a* 값 $4.68, \mathrm{~b}^{*}$ 값 $6.04, \mathrm{pH} 5.61$, 육색도 3.61 , 근내지방도 3.36 , 육질 등급 1.83 , 그리고 육량등급 2.08 로 조사되었다. 성별 도체특성에 서 도체중은 암퇘지가 $75.69 \mathrm{~kg}$ 으로 거세돈 $71.71 \mathrm{~kg}$ 보다 유의하 게 무거웠으나 $(\mathrm{p}<0.05)$, 도체율, 등지방두께, 그리고 육색도에서는 성별 간에 모두 유의한 차이가 없었다. $\mathrm{pH}$ 는 암퇘지와 거세돈에서 각각 5.58과 5.62 로 거세돈이 유의하게 높게 나타났다 $(\mathrm{p}<0.05)$.
도체육질등급에서는 거세돈과 암퇘지의 평균등급은 1.95 와 1.58 로 거세돈이 유의하게 높은 등급을 보였다 $(\mathrm{p}<0.05)$. 그리고 육량등급 에서도 성별 간에 유의한 차이를 보였는데 $(\mathrm{p}<0.05)$, 거세돈 1.90 등급보다 암퇘지 2.50 등급으로 암퇘지가 높게 나타났다. 도체 육 질등급별 도체특성에서는 도체중은 도체등급이 높을수록 유의하게 무거운 것으로 나타났으며 $(\mathrm{p}<0.05)$, 도체율에서도 도체육질등급이 높을수록 (1과 2 등급) 유의하게 높은 것으로 나타났다 $(\mathrm{p}<0.05)$. 등 지방 두께는 등급 간에 유의한 차이를 보였는데 $(\mathrm{p}<0.05)$, 등급이 높을수록 등지방 두께가 높았다. 육색도에서는 등급 간에 Hunter $\mathrm{L}^{*}$ 값, $\mathrm{a}^{*}$ 값, $\mathrm{b}^{*}$ 값 모두 유의한 차이를 보이지 않았다. 근내지방 도는 1 등급은 4.06점과 3등급은 2.64점으로 등급이 높을수록(양 호) 유의하게 $(\mathrm{p}<0.05)$ 높은 점수를 보였다. 도체 육량등급별 도체 특성에서 도체중과 도체율은 등급 간에 모두 유의한 차이를 보였는 데 $(\mathrm{p}<0.05)$, 등급이 높을수록 (A 등급) 체중이 무겁고 도체율이 높 은 것으로 나타났다. 등지방두께는 $\mathrm{A}$ 등급은 $22.83 \mathrm{~mm}$ 로 유의하게 높은 $(\mathrm{p}<0.05)$ 반면에, $\mathrm{D}$ 등급은 $18.63 \mathrm{~mm}$ 로 등급이 낮을수록 등 지방두께도 얇았다. 육색도는 Hunter $\mathrm{L}^{*}$ 값, $\mathrm{a}^{*}$ 값, $\mathrm{b}^{*}$ 값 모두 등급 간에 유의한 차이가 발견되지 않았으나, $\mathrm{pH}$ 값은 $\mathrm{A}$ 등급에 서 5.53으로 하위등급보다 유의하게 높은 것으로 나타났다 $(\mathrm{p}<0.05)$. 육색도판에 의한 육색도에서도 유의한 차이를 보였다 $(\mathrm{p}<0.05)$. 근내지방도는 등급 간에 유의한 차이를 보였는데 $(\mathrm{p}<0.05)$, 상위 $\mathrm{A}, \mathrm{B}$ 등급에서는 4.00 이상으로 높았으나, 하위 $\mathrm{C}$ 와 $\mathrm{D}$ 등급에서는 3.06 이하의 낮은 점수로 나타났다. 따라서 제주 재래종은 개량종보다 등지방두께는 양호하였으나, 육질과 관련된 특성을 더욱 더 심도있는 비교연구로 정확한 평가가 이루어져야 할 것으로 생각된다.

\section{사 사}

본 연구는 2009학년도 공주대학교 자체연구비 지원으로 수행되 었으며, 이에 감사드립니다.

\section{인 용 문 헌}

김계웅, 김석은. 2009. 돼지의 교배조합 - 도체등급 및 출하일령이 도체특 성에 미치는 영향. 한국동물자원과학회지. 51(1):69-74.

김계웅, 임병순. 2006. 돼지의 도체중과 등지방 두께에 따른 도체 등급 및 도체 특성. 한국축산식품학회지. 26(2):183-188.

박만종, 정진연, 하덕민, 한정철, 심태건, 박병철, 박구부, 주선태, 이철영. 2009. 비육돈에서 사료의 에너지 수준과 도살체중이 성장성적과 도체 의 등급 및 육질특성에 미치는 영향. 한국동물자원과학회지. 51(2): 143-154.

박준철, 김영화, 정현정, 박범영, 이정일, 문홍길. 2005. 출하체중에 따른 재래돼지와 랜드레이스의 도체 및 돈육의 이화학적 특성 비교. 한국동 물자원과학회지. 47(1):91-98.

오하식, 김현열, 양한술, 이정일, 주영국, 김철욱. 2008. 돼지 품종의 교배 
조합간 육질특성 비교. 한국축산식품학회지. 28(2):171-180.

이성기, 주명규, 김용선, 강선문, 최염순. 2005. 재래종과 개량종 세절 돼지 고기의 저장 중 품질 특성 비교. 한국축산식품학회지. 25(1):71-77.

조수현, 박범영, 김진형, 김명직, 성필남, 김영종, 김동훈, 안종남. 2007a 재래돼지의 출하체중별 도체수율 및 육질특성. 한국동물자원과학회지. 49(4):523-530.

조수현, 성필남, 김진형, 박범영, 권오섭, 하경희, 김동훈, 안종남. 2007b. 재래돼지의 성별에 따른 육질, 영양학적 조성 및 관능특성 비교. 한국 축산식품학회지. 27(4):475-481.

진상근, 김일석, 송영민, 허선진, 하경희, 김회윤, 류현지, 하지희, 김병우. 2004. 교잡종 돼지에서 도체등급에 따른 돈육의 이화학적 특성 변화. 한국축산식품학회지. 24(3):246-252.

진상근, 김일석, 허선진, 하경희, 김병우. 2005. 재래돼지와 랜드레이스 교 잡종 돼지에서 출하체중에 따른 돈육의 이화학적 특성. 한국국제농업 개발학회지. 17(3):182-187.

최염순, 박범영, 이종문, 이성기. 2005. 재래흑돼지와 개량종 돼지의 도체 및 육질 특성 비교. 한국축산식품학회지. 25(3):322-327.

최염순, 박범영, 이종문, 채병조, 이성기. 2008. 사료의 영양수준에 따른 재 래흑돼지의 산육능력 및 육질비교. 한국축산식품학회지. 28(1):39-44.

최재관, 전광주, 이준헌, 김동훈, 김종복. 1996. 돼지의 도체형질에 미치는 환경요인의 추정. 농업논문집. 38(1):763-769.

Choi, Y. S. 2004. Studies on the pork quality of Korean native black pigs and its improvement through dietary manipulation. Ph.D thesis, Kangwon National University, Chuncheon, Korea. pp. $1-169$.

Hong, K. C., Kim, B. C., Son, Y. S. and Kim, B. K. 2001. Effects of the mating system on fattening performance and meat quality in commercial pigs. Journal of Animal Science and Technology. 43(2):139-148.

Jin, S. K., Kim, C. W., Song, Y. M., Jang, W. H., Kim, Y. B., Yeo,
J. S., Kim, J. W. and Kang, K. H. 2001. Physicochemical characteristics of longissimus muscle between the Korean native pig and Landrace. Korean Journal Food Science Animal Resources. 21(2):142-148.

Jin, S. K., Kim, I. S., Hur, S. J., Kim, S. J. and Jeong, K. J. 2006. The influence of pig breeds on qualities of loin. Journal of Animal Science and Technology. 48(5):747-758.

Kwon, O. S. 2006. Preservation background and environmental status of Korean native black pigs. Symposium proceedings of preservation and utilization of Korean native black pigs. National Institute of Animal Science, RDA, April 21. pp. 3-20.

Larzul, C., Lefaucheur, L., Ecolan, P., Gogue, J., Talmant, A., Sellier, P., Le Roy, P. and Monin, G. 1997. Phenotypic and genetic parameters for longissimus muscle fiver characteristics in relation to growth, carcass, and meat quality traits in Large White pigs. Journal of Animal Science. 75:3126.

Martens, H. 1998. Physiologie der Muskulature und das MHS-Gen Schweines: Zur Diskussion um eine Eliminierung des mutierten Ryanodin Rezeptors aus der deutschen Schweinezucht. Arch. Tierzucht. Dummersdorf. 41:179-192.

Sather, A. P., Jones, D. M., Tong, A. K. W. and Murray, A. C. 1991. Halothane genotype by weight interactions on pig meat quality. Canadian Journal of Animal Science. 71:645-658.

Warriss, P. D., Brown, S. N., Edwards, J. E. and Knowles, T. G. 1995. Effect of lairage time on levels of stress meat quality in pigs. Proceedings of EU-Seminar: New Information on welfare and meat quality of pigs related to holding, transport and lairage conditions, Mariensee, Germany. pp. 163-170.

(접수일자 : 2010. 4. 7 / 수정일자:2010. 5. 26 / 채택일자 : 2010. 7. 20) 